\title{
POVRŠINE I PROCJENA POLJOPRIVREDNOG ZEMLJIŠTA U HRVATSKOJ
}

\author{
AREA AND AGRICULTURAL LAND EVALUATION IN CROATIA
}

\section{Ž. Vidaček}

\section{SAŽETAK}

Potpuno točnih podataka o korištenju poljoprivrednog zemljišta u Hrvatskoj nema zbog ne sređene nacionalne baze podatka, odnosno nepovezanosti nadležnih tijela u provođenju učinkovite zemljišne politike. Ne postoji jedinstvena evidencija o poljoprivrednom zemljištu i o oblicima uporabe i raspolaganja. Katastar nije usklađen s gruntovnicom, a to dvoje nije usklađeno sa stvarnim stanjem. Od 60-tih i 70-tih godina prošlog stoljeća u Hrvatskoj se koriste: Bonitiranje zemljišta, Kovačević P. i sur. 1987., Kovačević P. (1983.), Pravilnik o mjerilima za utvrđivanje osobito vrijednog obradivog (P1) i vrijednog obradivog (P2) poljoprivrednog zemljišta, NN 23/19, te Okvir za procjenu zemljišta, FAO 1976 u dorađenoj verziji Vidaček Ž., 1981. Preporučena je primjena uz doradu FAO okvira procjene zemljišta, ibidum. U cilju kvalitetne implementacije predloženo je osnivanje „Projektnog savjeta za procjenu poljoprivrednog zemljišta Hrvatske“ pri Ministarstvu poljoprivrede, Hrvatske agencije za poljoprivredu i hranu, Centru za tlo, dakako u suradnji sa znanstvenim institucijama.

Ključne riječi: tlo, zemljište, procjena, pogodnost, poljoprivreda, Hrvatska

\begin{abstract}
Fully accurate data on the use of agricultural land in Croatia are missing due to disordered national database, that is, the incompatibility of the competent authorities in the implementation of an effective land policy. There is no uniform record of agricultural land, forms of use and management. The cadastre is not aligned with the land register, and the two are not aligned with the actual situation. Since the 1960s and 1970s, the following have been used in Croatia: Land evalation, Kovačević P. et al. 1987, P. Kovačević (1983), Ordinance on
\end{abstract}


the criteria for determining particularly suitable arable (S1) land and suitable arable (S2) land, NN 23/19, and finally A Framework for Land evaluation, FAO 1976, as revised by Vidaček Ž., 1981. The implementation of the FAO Framework is recommended to be refined and we propose the establishment of a "Project Council for Agricultural Land evaluation in Croatia" at the Ministry of Agriculture, Croatian Agency for Agriculture and Food, Soil Center, in collaboration with scientific institutions.

Key words: soil, land, evaluation, suitability, agriculture, Croatia

\section{UVOD}

Poljoprivredno tlo je temeljni resurs za proizvodnju hrane i nezamjenjivo nacionalno bogatstvo. Obradivo zemljište je temelj ratarske, voćarske, vinogradarske i povrtne proizvodnje, a livade i pašnjaci stočarske proizvodnje. Porastom stanovništva, ono je u nas i u svijetu intenzivno korišteno, degradirano, oštećeno, onečišćeno i dijelom izgubljeno prenamjenom. Za zaustavljanje ili u najmanju ruku ublažavanje ovog negativnog trenda u Hrvatskoj, trebamo imati pouzdane podatke o površini i kvaliteti poljoprivrednog zemljišta za potrebe racionalnog planiranja korištenja, uređenja, održavanja i zaštite poljoprivrednog zemljišta ${ }^{1}$. U nas se najčešće koriste podaci o površini državnog i privatnog poljoprivrednog zemljišta iz nepouzdane statistike i neuređenog zemljišno knjižnog sustava.

Aktualni pravilnik kojim se propisuju mjerila i osnove za vrednovanje (bonitiranje) vrijednog poljoprivrednog zemljišta je kompliciran i ograničeno uporabiv za izazove moderne, produktivne i konkurentne poljoprivrede.

Prema vlastitom izboru procjenitelja Okvir za procjenu zemljišta, FAO 1976, se do današnjih dana koristio za procjenu pogodnosti poljoprivrednog tla za obradu, za uzgoj poljoprivrednih kultura, za potrebe prostornog planiranja, zaštitu poljoprivrednog tla, te planiranje i projektiranje hidro i agromelioracija s odvodnjom i/ili natapanjem.

\footnotetext{
${ }^{1}$ Tla moraju biti zaštićena, zbog proizvodnih kapaciteta, doprinosa sigurnosti hrane, održavanja ravnoteže agroekosustava. Tlo je ograničen resurs. Gubici i degradacija tla nisu nadoknadivi unutar ljudskog životnog vijeka. Procjenjuje se da je 52 posto poljoprivrednog zemljišta u svijetu umjereno ili ozbiljno degradirano, a gotovo 2 milijarde hektara - površina dvostruko veća od Kine - ozbiljno je degradirano.
} 
1. Koliko Hrvatska ima poljoprivrednog zemljišta-dokumenti i komentari

Hrvatska nema potpuno točnih podataka o površini, kvaliteti (bonitetu) i trajnom gubitku poljoprivrednog zemljišta. Problem je u katastru, gruntovnici i nepouzdanim podacima statistike.

Ukupna površina poljoprivrednog zemljišta u Republici Hrvatskoj je 2.695.037 ha, a od toga je u vlasništvu države 890.214 ha ili 33\%, a 1.804 .823 ha ili $67 \%$ je u privatnom vlasništvu. Podaci se temelje na podacima Statističkog ljetopisa iz 2005. Nacrt prijedloga zakona o poljoprivrednom zemljištu, 2013.

Oranica, voćnjaka, vinograda i livada u Hrvatskoj ima 1.998 .000 ha (63\%), a pašnjaka 1.153 .000 ha $(37 \%)$. Od ukupnog fonda poljoprivrednog zemljišta dvije trećine je u vlasništvu privatno. Na jednog stanovnika u Hrvatskoj otpada 0,70 ha poljoprivrednog zemljišta ili 0,44 ha pašnjaka, Vidaček Ž., 2001.

Različiti dokumenti donose podatke od 1,7 do 3,1 milijuna hektara poljoprivrednog zemljišta, u kojem se udjel privatnog vlasništva procjenjuje na 67 do 84 posto. Koliko (ne)obrađenog zemljišta Hrvatska ima ukupno, taj je odgovor još u sferi nepoznanice. Statistički podaci o korištenju zemljišta najproblematičniji su od svih poljoprivrednih podataka. U Strategiji gospodarenja poljoprivrednim zemljištem, 2001. godine stoji podatak o $3,187.494$ ha poljoprivrednog zemljišta. I to u privatnom vlasništvu 2,043.767 i državnom 1,143.727 ha. Strategija kaže da su 400.000 državnih hektara oranice, a ostalo je neobrađeno zemljište. Autori navode da su koristili podatke Državnog zavoda za statistiku iz 1999. godine. Statistički godišnjak za 2004. (podaci katastra) spominje 3,14 milijuna ha od kojih je 67 posto u privatnom, a 33 posto u državnom vlasništvu. Akademik Vladimir Stipetić, u studiji o Urgentnim zadacima hrvatske agrarne politike prije pristupanja EU, svibanj 2005., iznosi da je 1939. bilo 3,526.000 hektara, a 1989. godine 3,244.000 ha. Međutim, po Upisniku poljoprivrednih gospodarstava iz 2003. dobiven je podatak o samo 1,077.404 ha, od kojih je pod oranicama, vrtovima, voćnjacima i vinogradima bilo 808.202 ha. Prema Upisniku 84 posto zemljišta je u privatnom vlasništvu dok je 16 posto od poslovnih subjekata. Ima naznaka da su seljaci u strahu od novih poreza za Upisnik davali netočne informacije. Razlika nije zanemariva. Je li "nestala" u zapuštenim, neobrađenim površinama? Ili su nekadašnje oranice nasilnom urbanizacijom pretvorene u građevne parcele? I dvojbe takve naravi traže odgovor. Nesređena evidencija veliki je minus nacionalne baze podataka. Primjerice, Strategija govori da je pod vinogradima bilo 59.000 ha, a Upisnik svjedoči da pod vinogradima ima upola manje, odnosno 28.000 ha. Hrvatski zavod za vinogradarstvo i vinarstvo prionuo je 
izradi katastra vinograda. Iz odrađenog posla zna se da u Vukovarskosrijemskoj županiji ima 1055 ha vinograda, u Varaždinskoj 2067 te Krapinskozagorskoj 2.229 ha. Katastar Istarske županije pod vinogradima vodi 4278, a u Primorsko-goranskoj županiji 148 ha. Vlada je najavljivala, da će u 2007. proraditi Agencija za promet poljoprivrednim zemljištem. Državna zemlja veliki je problem, još veći je ona u privatnom vlasništvu. Premda Zakon o poljoprivrednom zemljištu, članak 56 propisuje da se obiteljsko poljoprivredno zemljište ne može nasljeđivanjem dijeliti, iz prakse se očitava da je ta odredba stigla sa zakašnjenjem. S parcelama manjim od pet hektara raspolaže čak 68,67 posto obiteljskih gospodarstava. Samo 2,34 posto hrvatskih farmera ima između 20 i 50 hektara, a iznad 50 ha tek 0,93 posto. Prosječno EU obiteljsko gospodarstvo vlasnik je od 3,5 na Cipru preko 67 u Češkoj do 79 ha u Velikoj Britaniji. Zadaća Agencije bila bi staviti u funkciju i državnu i privatnu (ne)obrađenu zemlju, a vlasnicima koji nisu poljoprivrednici osigurati naknadu. Tko ne dopusti racionalno korištenje oranica plaćao bi porez na korov. Priča o korovu traje godinama i nažalost, nije odmakla dalje od ideje. O porezu na korov govori se od 2001. Za svaki hektar zanemarenog voćnjaka ili vinograda kazna je 1000 kuna, za neobrađene povrtnjake 800 , oranice 500, a livade 250 kuna. Porez na korov, međutim, nitko ne ubire. Grad Kutina je proračunom za 2004. "korovom" planirao ubrati 10.000 kuna! Od teorije do prakse veliki je procjep. Unatoč obvezi (Zakon o financiranju jedinica lokalne samouprave) u općinama i gradovima ističu da za primjenu poreza na korov čekaju naputke države. I dok je u Švedskoj ili Danskoj najnormalnija pojava da nasljedniku, koji se ne misli baviti poljoprivredom, državna agencija uzima zemlju (ustupa je farmerima) uz isplatu novčane naknade bit će zanimljivo vidjeti hoće li aktualna Vlada imati petlju narediti lokalnoj vlasti aktiviranje zakonske poluge o porezu na obradivo neobrađeno zemljište, Babić Božica, 2007.

Udruga obiteljskih poljoprivrednih gospodarstava „Život“ o neobrađenom poljoprivrednom zemljištu, https://požeška-kronika.hr/, 2018. Popis ukupno raspoložive državne zemlje ne postoji, a ono što se može naći je manjkavo, netočno i netransparentno, te takav lako može postati predmet manipulacija. U Agenciji za poljoprivredno zemljište navode da u RH ima ukupno 2.695.037 ha poljoprivredne zemlje od toga oni raspolažu sa 738.125 ha neobrađene zemlje. Obrađuje se oko 1.100 .000 ha, i sada dolazimo do toga da ne znamo gdje je 850.000 ha, a po tome do katastrofalnog podatka, da se u RH obrađuje samo $40 \%$ poljoprivrednog zemljišta. 
Površina korištenog poljoprivrednog zemljišta od 2005.-2017.godine, varira od oko 1.201.756 ha do 1.568.881 ha. Obradivog zemljišta bude 919.559 989.436 ha i permanentnih travnjaka maksimalno 628.070 ha. Od pojedinačnih godišnjih podataka navodimo 2016. godinu s 1,56 milijuna hektara poljoprivrednih površina, od čega su oranice i vrtovi 895 tisuća hektara $(57,2 \%)$, a trajni travnjaci 597 tisuća hektara $(38,1 \%)$. Pod trajnim nasadima su voćnjaci, vinogradi, maslinici, rasadnici i košaračka vrba 72 tisuće hektara, DZS, 2018.

\section{Zemljišno knjižni sustav}

Davnih vremena, na IX. kongresu Hrvatskog tloznanstvenog društva s međunarodnim sudjelovanjem i ambicioznom agendom „Gospodarenje i zaštita tla u Hrvatskoj-Globalno stanje i preporuke“, 2001. godine, Kristina Svržnjak i Žimbrek T. upozoravaju, da je jedan od preduvjeta dobrog gospodarenja i zaštite tla za buduće naraštaje dobro ustrojena ubilježba poljoprivrednog zemljišta. Osnovni problem tada i danas nakon osamnaest godina je nepovezanost nadležnih tijela u provođenju učinkovite zemljišne politike Državne geodetske uprave, Županijskih ureda za katastar i geodetske poslove, Ministarstva poljoprivrede i šumarstva, Uprave za gospodarenje poljoprivrednim zemljištem, Državnog zavoda za statistiku i sl., odnosno što ne postoji jedinstvena evidencija o poljoprivrednom zemljištu, te oblicima uporabe i raspolaganja. Takav zemljišno - knjižni sustav ne odgovara potrebama tržišnog gospodarstva.

U Vladinom planu reformi upisano je i uređivanje zemljišnih knjiga kao preduvjet za oživljavanje investicijske aktivnosti. A kakvo je stanje zemljišnih knjiga u Hrvatskoj, najbolje je dočarao Mladen Fogec, predsjednik Udruge stranih investitora u Hrvatskoj. Katastar nije usklađen s gruntovnicom, a to dvoje nije usklađeno sa stvarnim stanjem. U Hrvatskoj imamo 3500 katastarskih općina, od njih 220 uopće nema knjige, a 70 posto njih je ažurirano u 19. stoljeću', opisao je Fogec, govoreći nedavno za TVN1 o potrebi hitne reforme zemljišnih knjiga, www.tportal.hr $>$ biznis $>$ clanak, 2016. godine. Ministarstvo uprave je još u 2017. godini najavilo velike projekte za iduću godinu, među kojima i intenzivan rad na spajanju zemljišnih knjiga i katastra, te na uspostavi Informacijskog sustava prostornog uređenja (ISPU), usavršavanje sadašnjih i izrada novih modula: e-dozvola, e-inspekcija, e-nekretnina, e-arhiva. „Kao jednu od reformskih mjera, Vlada je prihvatila spajanje katastra i zemljišnih knjiga u jednu instituciju. Smatram, kako je to "reforma svih reformi". Naime, 
danas imamo vrlo nesređeno stanje u katastru i zemljišnim knjigama, što sprječava velike investicije i stvara probleme našim sugrađanima bilo da je riječ o velikim investicijama, nasljeđivanju, kupoprodaji ili nečemu drugome. Vlada je prepoznala problem i prihvatila tu reformsku mjeru. Iskoristit ćemo 2017. da zajedno s Ministarstvom pravosuđa promijenimo potrebne zakonske propise, nakon čega počinje provedba od 2018. do 2020. godine. Ističem kako smo prvi korak u tome napravili, a to je Zajednički informacijski sustav (ZIS). U ZIS smo u deset mjeseci mog mandata uveli 50 posto Hrvatske, rekao je ministar uprave 2016.godine, http://www.poslovni.hr/hrvatska/kuscevic-spajanje-gruntovnice-ikatastra-do-2020-321950.

\section{Procjena-bonitiranje poljoprivrednog zemljišta i tla u Hrvatskoj}

Od 60-tih i 70-tih godina prošlog stoljeća u Hrvatskoj se koriste: Bonitiranje zemljišta, Kovačević P. i sur. 1987., Kovačević P. (1983.), Pravilnik o mjerilima za utvrđivanje osobito vrijednog obradivog (P1) i vrijednog obradivog (P2) poljoprivrednog zemljišta, NN 23/19, koji najvećim dijelom koristi sadržaje i kriterije ranije navedenog bonitiranja zemljišta, te Okvir za procjenu zemljišta, FAO 1976 u dorađenoj verziji Vidaček Ž., 1981.

\subsection{Bonitiranje zemljišta Kovačević}

Radovi na izradi nove metode bonitiranja zemljišta započeti su 1972. i završili 1976. godine zajedničkim radom stručnjaka Republičke geodetske uprave Hrvatske i znanstvenika Fakulteta poljoprivrednih znanosti u Zagrebu, te Instituta za šumarska istraživanja u Zagrebu

Bonitet zemljišta je prirodna proizvodna sposobnost zemljišta uvjetovana konstelacijom prirodnih čimbenika trajnog značenja: tlom, klimom, reljefom i ostalim prirodnim uvjetima. Izražava se u poenima ili klasama. Bonitiranje zemljišta vrši se bez obzira na postojeći način korištenja. Bonitiranje zemljišta u odnosu na pedološku kartografiju predstavlja kvalitativno novi pristup prikazivanja pedološkog pokrivača nekog prostora. Potrebno je razlikovati bonitiranje tala prema njihovim unutarnjim svojstvima i bonitiranje zemljišta, koje obuhvaća bonitiranje tla, reljefa i klime, te ostalih prirodnih uvjeta. Tla optimalnog boniteta su u pravilu duboka, eutrofna (neutralne do slabo kisele reakcije), ilovaste teksture, dobre vodopropusnosti, postupnog prijelaza horizonta iz jednog u drugi, bez zbijenih slojeva. 
Pravilnik o bonitiranju zemljišta propisuje mjerila i osnove po kojima se utvrđuju pogodnosti tla, klime, reljefa $\mathrm{i}$ ostalih prirodnih uvjeta za poljoprivrednu proizvodnju, pa se time ocjenjuje i opći stupanj mogućnosti svestranog korištenja zemljišta. Bonitet zemljišta prema ovom istovjetan je pojmu općeg boniteta zemljišta. Opći bonitet zemljišta ne može u potpunosti zadovoljiti svim zahtjevima za utvrđivanje određenog optimalnog stanja ili budućeg načina korištenja zemljišta, pa tada govorimo o bonitetu zemljišta katastarskih kultura ili biljnih vrsta u poljoprivrednoj i šumarskoj proizvodnji. Bonitet zemljišta katastarskih kultura utvrđuje se na temelju boniteta tla, reljefa i klime, te ostalih prirodnih uvjeta $u$ odnosu na specifične zahtjeve svake katastarske kulture posebno. U metodici utvrđivanja boniteta zemljišta ocjenjuju se četiri prirodna faktora kojima je određen opći bonitet zemljišta bez korekcije: bonitet tla, bonitet vodnog režima tla, bonitet klime i bonitet reljefa. Osobine tla su glavni i osnovni faktor vrijednosti odnosno proizvodne sposobnosti zemljišta $u$ istom klimatu. Tlo je onaj faktor boniteta zemljišta po kojem i prema raznolikostima reljefa možemo objektivno i praktično najlakše razvrstati zemljišta u bonitetne klase. Detaljnije o bonitiranju zemljišta u Hrvatskoj i osnivanju katastra ${ }^{2}$ zemljišta vidi, Kovačević P. 1983., Kovačević P. i sur. 1987.,

\subsection{Utvrđivanje vrijednog obradivog poljoprivrednog zemljišta NN 23/19}

Pravilnik o mjerilima za utvrđivanje osobito vrijednog obradivog (P1) i vrijednog obradivog (P2) poljoprivrednog zemljišta, stupio je na snagu 16. ožujka 2019. godine. Mjerila za razvrstavanje zemljišta u osnovi su preslika Bonitiranja zemljišta, Kovačević P. i sur. 1987.

Prostorne kategorije zemljišta u koje se svrstavaju poljoprivredna zemljišta su: P1 - osobito vrijedna obradiva zemljišta, P2 - vrijedna obradiva zemljišta, P3 - ostala obradiva zemljišta, PŠ - ostala poljoprivredna zemljišta. Procjenjuju se prema vrijednosti od najpovoljnijih do nepovoljnijih tala prema bonitetnim svojstvima tla, klime, reljefa i ostalih prirodnih uvjeta, Članak 5 Pravilnika.

Osnova za bonitiranje i utvrđivanje prostornih kategorija, osobito vrijednog obradivog (P1) zemljišta, vrijednog obradivog (P2) zemljišta, ostalih obradivih (P3) zemljišta, ostalih poljoprivrednih (PŠ) zemljišta su bonitetne pedološke

\footnotetext{
${ }^{2}$ Evidencija zemljišta i zemljišnih parcela na kojoj se zasnivaju zemljišne knjige i nekada su se i u nas određivali odgovarajući porezi
} 
karte detaljnog mjerila (1:2.000 do 1:5.000), koje vrednuju zemljišta na razini najmanje proizvodne parcele. Bonitetno vrednovanje mogu obavljati samo stručnjaci na području pedologije, Članak 29 Pravilnika.

\subsection{Okvir za procjenu zemljišta FAO u dorađenoj verziji Vidaček, Ž. 1981}

Dorađena verzija Okvira za procjenu zemljišta FAO, 1976., testirana je semidetaljnom procjenom pogodnosti tala za natapanje poljoprivrednih kultura i detaljnom procjenom pogodnosti tala za natapanje kukuruza, sve na širem i užem području istočne Slavonije i Baranje.

Nakon uspješnog testiranja, Okvir za procjenu zemljišta FAO u dorađenoj verziji je korišten za procjenu pogodnosti poljoprivrednog tla za obradu, za uzgoj poljoprivrednih kultura, za potrebe prostornog planiranja, zaštitu poljoprivrednog tla, te planiranje $\mathrm{i}$ projektiranje hidro $\mathrm{i}$ agromelioracija $\mathrm{s}$ odvodnjom $\mathrm{i} / \mathrm{ili}$ natapanjem. U procjenama su korišteni podaci Osnovne pedološke karte Hrvatske, mjerila 1:50 000. Za problematiku reljefa, korištene su topografske karte, za klimu meteorološki i klimatski podaci. Geološke i hidrogeološke karte izvor su podataka za matičnu stijenu ili matični supstrat tla i vodni režim tla.

3.3.1: Semidetaljna procjena pogodnosti poljoprivrednih tala za natapanje $u$ istočnoj Slavoniji i Baranji

Principi procjene: i. Zemljište ${ }^{3}$ je parcela, izvor hrane i dobara, imovina i vlasništvo, a tlo je sui generis prirodno tijelo-stanište za biljke, ii. Pogodnost zemljišta procjenjuje se i razvrstava za određene vrste korištenja, iii. Procjena zahtijeva usporedbu dobivenih koristi i ulaganja za različite vrste zemljišta, iv. Potreban je multidisciplinarni pristup, v. Procjena zemljišta treba obuhvatiti kako fizičke tako i ekonomske uvjete, vi. Pogodnost se mora temeljiti na održivosti korištenja zemljište, vii. Potreban je multidisciplinarni pristup, viii. Procjena zahtijeva usporedbu između dva ili više alternativnih načina korištenje, ix. Procjenom se može utvrditi aktualna i potencijalna pogodnost korištenja zemljišta. Potencijalna pogodnost tla ili zemljišta odnosi se na stanje poslije melioracijskih zahvata.

\footnotetext{
${ }^{3} \mathrm{U}$ postupku procjene zemljišta budu obuhvaćeni: fizikalni prostor - tlo, klima, reljef, vegetacija, hidrološke i geološke značajke u opsegu mogućeg korištenja, zatim rezultati aktivnosti čovjeka i društveno-ekonomski uvjeti, a u postupku procjene tla ocjenjujemo samo njegove fizikalne i kemijske značajke s reljefom (nagib terena), klimom (tuča, mraz magla, poplave) i rezultatima aktivnosti čovjeka, bez procjene društveno ekonomskih uvjeta.
} 
Kriteriji procjene: Pedosistematske jedinice projektnog područja procjenjuju se i svrstavaju u redove, klase i potklase pogodnosti. Redovi obilježavaju pogodnost $(\mathrm{P})$ ili nepogodnost $(\mathrm{N})$, klase stupanj pogodnosti odnosno P-1 pogodna, P-2 umjereno pogodna, P-3 ograničeno pogodna, te N-1 privremeno nepogodna i $\mathrm{N}-2$ trajno nepogodna tla za namjensko korištenje. Klase P-1 su pogodna tla bez značajnih ograničenja za korištenje ili $\mathrm{s}$ ograničenjima koja neće značajno utjecati na produktivnost i dobit. Klase P-2 su umjereno pogodna tla, s ograničenjima koja umjereno ugrožavaju produktivnost i dobit. Klase P-3 su ograničeno pogodna tla, s ograničenjima koja znatno ugrožavaju produktivnost $\mathrm{i}$ dobit. Klase $\mathrm{N}-1$ su privremeno nepogodna tla, $\mathrm{s}$ ograničenjima koja u postojećem stanju isključuju tehnološki i/ili ekonomski opravdano korištenje i Klase N-2 su trajno nepogodna tla, s ograničenjima koja trajno isključuju mogućnost tehnološki i/ili ekonomski opravdano korištenje.

Potklase pogodnosti ili nepogodnosti određene su prema vrstama ograničenja, kako slijedi: PKv-mali kapacitet tla za vodu ispod $15 \%$ vol., i-infiltracija $120 \mathrm{~cm} /$ dan $>\mathrm{k}_{\mathrm{i}}>3 \mathrm{~cm} /$ dan, d-dreniranost, $\mathrm{rn}_{1}$-nagib 8-15\%, $\mathrm{rn}_{2}$-nagib preko $15 \%$, rr-ravan reljef, e-erozija, ed-efektivna dubina tla manja od $0,4 \mathrm{~m}$, g-sadržaj gline preko $35 \%$, pH-alkalizacija, nv-nadmorska visina preko 115 m.n.m. kao ograničenje zbog nemogućnosti racionalne distribucije vode za natapanje.

Rezultati procjene: $\mathrm{U}$ tablici 1 sumirani su rezultati semidetaljne procjene pogodnosti tala za natapanje u istočnoj Slavoniji i Baranji, ukupne bruto površine 613.142 hektara. Na Đakovačko-Vukovarskom ravnjaku, blagim padinama Baranjskog i Erdutskog brda, te na lesnim i riječnim terasama, ima ukupno bruto 218.051 hektara pogodnih tala za natapanje. Na bazenskom i inundacijskom području Drave, Save i Dunava ima bruto 128.893 hektara tala prioriteta za hidro i agromelioracije. 
Tablica 1. Procjena pogodnosti tala za natapanje poljoprivrednih kultura u istočnoj Slavoniji i Baranji

Table 1 Evaluation of soil suitability for irrigation of agricultural crops in eastern Slavonia and Baranja

\begin{tabular}{|c|c|c|c|}
\hline $\begin{array}{l}\text { Red } \\
\text { Order }\end{array}$ & $\begin{array}{l}\text { Klasa } \\
\text { Class }\end{array}$ & $\begin{array}{l}\text { Potklasa } \\
\text { Subclass }\end{array}$ & $\begin{array}{l}\text { Pedosistematske jedinice } \\
\text { Pedosystematic units }\end{array}$ \\
\hline \multirow{6}{*}{ 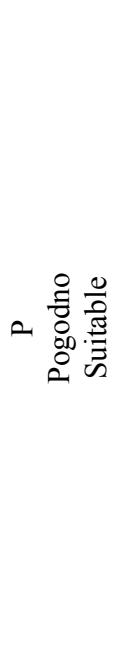 } & $\begin{array}{l}\text { P-1 } \\
\text { Pogodna } \\
\text { Suitable }\end{array}$ & $\begin{array}{l}\text { Neznatno- } \\
\text { Slightly }\end{array}$ & $\begin{array}{l}\text { Koluvijalna neoglejena ilovasta do } 115 \text { m.n.m., } \\
\text { Černozem na do } 115 \text { m.n.m., Černozem semiglejna, } \\
\text { Eutrično smeđa do } 115 \text { m.n.m., Eutrično smeđa } \\
\text { semiglejna, Lesivirana do } 115 \text { m.n.m., Lesivirana } \\
\text { semiglejna, Rigolana do } 115 \text { m.n.m., Aluvijalna } \\
\text { neoglejena ilovasta i Aluvijalna semiglejna }\end{array}$ \\
\hline & $\begin{array}{l}\text { P-2 } \\
\text { Umjereno } \\
\text { pogodna } \\
\text { Moderately } \\
\text { suitable }\end{array}$ & $\mathrm{rr}, \mathrm{d}, \mathrm{i}$ & $\begin{array}{l}\text { Lesivirana pseudoglejna do } 115 \text { m.n.m., } \\
\text { Lesivirana pseudoglejna i Hidromeliorirana }\end{array}$ \\
\hline & \multirow{4}{*}{$\begin{array}{l}\text { P-3 } \\
\text { Ograničeno } \\
\text { pogodno } \\
\text { Marginally } \\
\text { suitable }\end{array}$} & $\mathrm{Kv}, \mathrm{d}, \mathrm{i}$ & $\begin{array}{l}\text { Sirozem pjeskovita, Aluvijalna neoglejena pjeskovita } \\
\text { i Aluvijalna pjeskovita semiglejna }\end{array}$ \\
\hline & & $\mathrm{ed}, \mathrm{rn}_{1}, \mathrm{e}$ & Sirozem ilovasta do 115 m.n.m. \\
\hline & & $\mathrm{d}, \mathrm{ed}, \mathrm{rr}, \mathrm{i}$ & Pseudoglej zaravni \\
\hline & & ed, $d, i, e$ & Pseudoglej obronaka do 115 m.n.m. \\
\hline \multirow{7}{*}{ 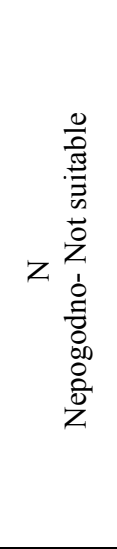 } & \multirow{2}{*}{$\begin{array}{l}\text { N-1 } \\
\text { Privremeno } \\
\text { nepogodno } \\
\text { Currently } \\
\text { Not Suitable }\end{array}$} & $\mathrm{v}, \mathrm{ed}, \mathrm{d}, \mathrm{i}$ & $\begin{array}{l}\text { Koluvijalna oglejena ilovasta do } 115 \text { m.n.m., } \\
\text { Aluvijalna oglejena ilovasta i pjeskovita, } \\
\text { Euglejna ilovasta i pjeskovita, Ritska crnica ilovasta } \\
\text { i Pseudoglej-glej }\end{array}$ \\
\hline & & $\mathrm{pH}, \mathrm{ed}, \mathrm{d}, \mathrm{i}$ & Solončak i Solonec \\
\hline & \multirow{5}{*}{$\begin{array}{l}\text { N-2 } \\
\text { Trajno } \\
\text { nepogodno } \\
\text { Permanently } \\
\text { Not Suitable }\end{array}$} & nv & $\begin{array}{l}\text { Černozemna, Eutrično smeđa i Lesivirana } \\
\text { preko } 115 \text { m.n.m. }\end{array}$ \\
\hline & & $\begin{array}{c}\mathrm{nv}, \mathrm{rn}_{1} \\
\mathrm{rn}_{2}, \mathrm{e}\end{array}$ & $\begin{array}{l}\text { Sirozem ilovasta, Distrično smeđa, Rigolana i Rendzina } \\
\text { preko } 115 \text { m.n.m. }\end{array}$ \\
\hline & & nv & Koluvijalna neoglejena i oglejena preko 115 m.n.m. \\
\hline & & $\mathrm{nv}, \mathrm{d}, \mathrm{v}, \mathrm{i}$ & $\begin{array}{l}\text { Lesivirana pseudoglejna i Pseudoglej obronaka } \\
\text { preko } 115 \text { m.n.m. }\end{array}$ \\
\hline & & $\mathrm{v}, \mathrm{g}$ & Močvarna glejna vertična i Ritska crnica vertična \\
\hline
\end{tabular}


3.3.2. Detaljna procjena pogodnosti poljoprivrednog tla, prinosa, vrijednosti proizvodnje i financijskih rezultata u primjeni natapanja kukuruza na tri lokacije $\mathrm{u}$ istočnoj Slavoniji i Baranji

Organizacija pokusa i obrada podataka: Dvogodišnji pokus je organiziran na lokaciji Klisa za černozem semiglejnio tlo, na lokaciji B. Pustara za aluvijalno semiglejno tlo i lokaciji Vinkovci za lesivirano semiglejno tlo. Korišten je klasični način kišenjem, Bc hibrid, kontrola vlage u tlu elektrometrijski i gips blokovi, analiza varijance za prinose zrna kukuruza po godinama i tlima u pokusu. Procjena pogodnosti tla za primjenu natapanja je prema FAO. Vrijednost proizvodnje, direktni troškovi proizvodnje i dobit po jednom hektaru poslužili su za ekonomsku ocjenu proizvodnje zrna kukuruza u pokusu. Za obračun i usporedbu korišteni su, uz navedeno, troškovi natapanjagodišnja otplata anuiteta za gravitacijski sustav na bazi 50-godišnje otplate i uz 8\% kamata, te prinosi suhog zrna kukuruza, Vidaček Ž. 1981.

Rezultat. Tla u pokusu imaju dobra vanjska i unutarnja svojstva, pa spadaju u P1 klasu dobre pogodnosti za natapanje kukuruza, vidi tablici 1. Prinosi zrna kukuruza na natapanim površinama su veći za 11,1\%-19,9\%. Vrijednost proizvodnje je na svim varijantama natapanja veća za 10-17\%. Međutim, financijski rezultati proizvodnje zrna kukuruza s natapanjem je negativan, zato što povećani prinosi zrna kukuruza ne pokrivaju direktne troškove i anuitete.

Primjer 3: Pogodnost i rasprostranjenost tala za uzgoj vinove loze u marijabistričkom kraju. Sistematske jedinice tala procijenjene su i svrstane u klase i podklase pogodnosti u tablici 2 i u tumaču Karte pogodnosti tla za uzgoj vinove loze područja Marije Bistrice, Vidaček Ž, Petrinec Z. i sur. 2015., slika 1.

Klasom je određen stupanj pogodnosti odnosno nepogodnosti tla, a podklasom su u konkretnom slučaju naznačena samo dominantna privremena ili/i trajna ograničenja, kao na primjer dubina tla, višak vode, nagib, erozija, ocjeditost, manjak biljnih hranjiva ili/i humus, višak vapna, magla i mraz. Privremena ograničenja mogu se otkloniti određenim melioracijskim mjerama. Šesnaest pedosistematskih jedinica, od čega su automorfne jedinice pogodne, umjereno pogodne ili ograničeno pogodne, te šest hidromorfnih jedinica $u$ nizinskom području s viškom vode u tlu kraćeg ili dužeg trajanja trajno su nepogodne za uzgoj vinove loze. 
Tablica 2. Procjena pogodnosti tla za uzgoj vinove loze na području Marije Bistrice

Table 2 Evaluatuin of soil suitability for grapevine cultivation in Marija Bistrica region

\begin{tabular}{|c|c|c|}
\hline $\begin{array}{l}\text { Klasa-Class } \\
\text { (Red-Order) }\end{array}$ & $\begin{array}{c}\text { Podklasa-Subclass } \\
\text { (Ograničenja-Limitation) }\end{array}$ & $\begin{array}{l}\text { Sistematske jedinice tala- } \\
\text { Pedosystematic units }\end{array}$ \\
\hline \begin{tabular}{|l} 
P-1 \\
Pogodna - Suitable
\end{tabular} & Neznatna & Lesivirano tlo na lesu \\
\hline $\begin{array}{l}\text { P-2 } \\
\text { Umjereno pogodno - } \\
\text { Moderately suitable } \\
\end{array}$ & $\begin{array}{l}\text { Hranjiva, } \\
\text { glina, humus }\end{array}$ & Eutrično smeđe glinasto tlo \\
\hline \multirow{6}{*}{$\begin{array}{l}\text { P-3 } \\
\text { Ograničeno pogodno - } \\
\text { Marginally suitable }\end{array}$} & $\begin{array}{l}\text { Višak vode dužeg trajanja, } \\
\text { ocjeditost, humus, hranjiva }\end{array}$ & Pseudoglej na zaravni \\
\hline & $\begin{array}{l}\text { Višak vode kraćeg trajanja, nagib, } \\
\text { ocjeditost, humus, hranjiva }\end{array}$ & Pseudoglej obronaka \\
\hline & $\begin{array}{l}\text { Dubina, nagib, erozija, } \\
\text { hranjiva, vapno }\end{array}$ & $\begin{array}{l}\text { Rendzina na laporu } \\
\text { Rendzina na vapnencu }\end{array}$ \\
\hline & $\begin{array}{l}\text { Dubina, nagib, erozija, humus, } \\
\text { hranjiva, vapno }\end{array}$ & $\begin{array}{l}\text { Sirozem na lesu, Sirozem na } \\
\text { laporu, Sirozem na vapnencu }\end{array}$ \\
\hline & $\begin{array}{l}\text { Dubina, nagib, erozija, humus, } \\
\text { kiselost, hranjiva }\end{array}$ & Kiselo smeđe tlo na pješčenjaku \\
\hline & Dubina, nagib, erozija, humus & Lesivirano na vapnencu \\
\hline $\begin{array}{l}\mathrm{N}-2 \\
\text { Nepogodno - Unsuitable }\end{array}$ & Magla, mraz & $\begin{array}{l}\text { Močvarna tla, Semiglejna, } \\
\text { Koluvijalna oglejena i neoglejena } \\
\text { Koluvijalna neoglejena }\end{array}$ \\
\hline
\end{tabular}


Ž. Vidaček.: Površine i procjena poljoprivrednog zemljišta u Hrvatskoj

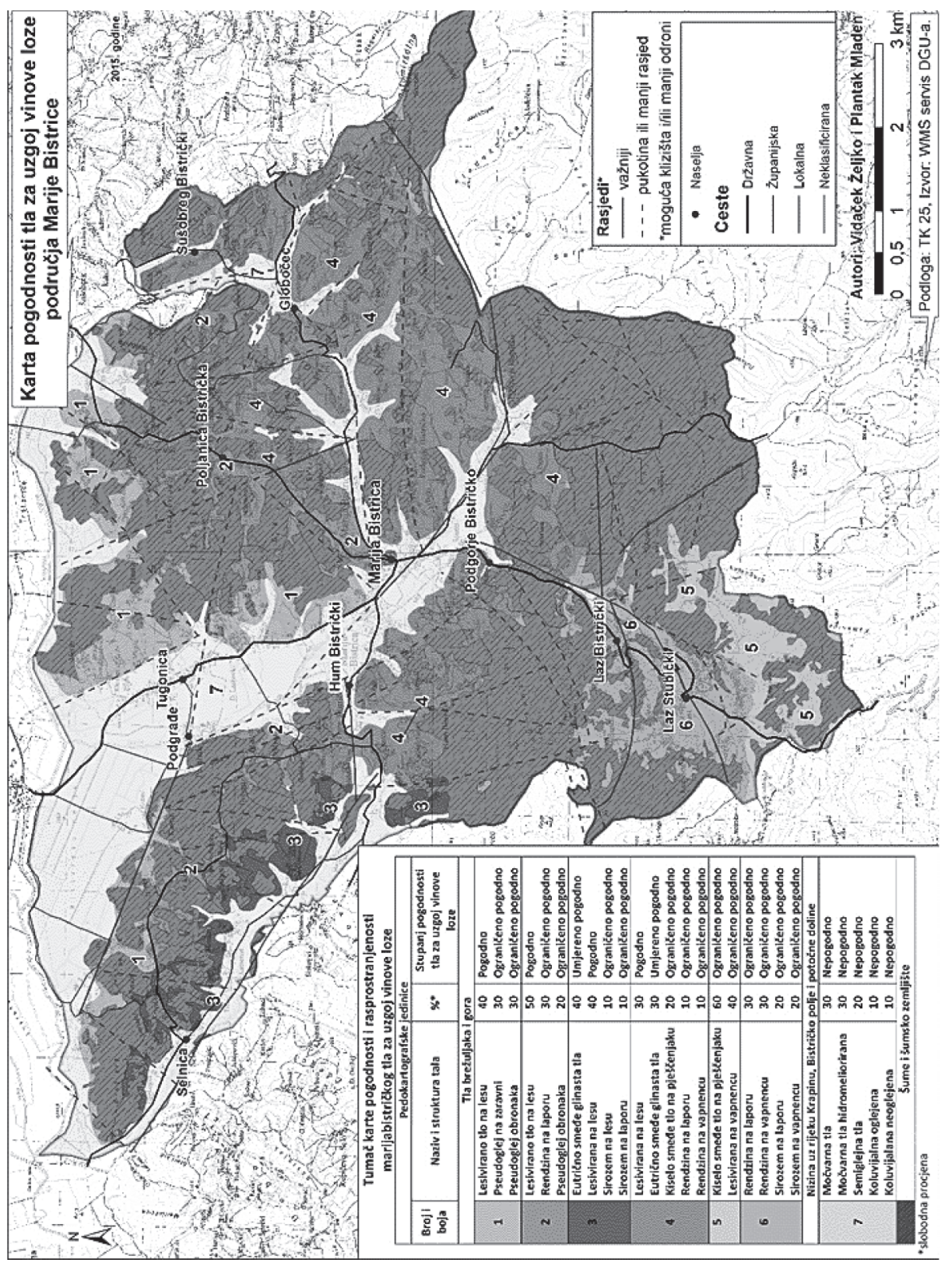

Slika 1.

Fig. 1 


\section{Preporuka}

Preporuka je izrada standardnog referentnog sustava „Procjena pogodnosti poljoprivrednog zemljišta Hrvatske“, digitalizacijom i provedbom dorađenog Okvira za procjenu zemljišta, FAO, ibidum, koji je i nakon nešto više od četrdeset godina najrašireniji sustav procjene zemljišta.

Cilj procjene navedenog sustava je stvoriti takve uvjete korištenja zemljišta koji najbolje odgovaraju njegovim značajkama uz minimum degradacije. Naše dosadašnje iskustvo u korištenju Okvira je pretežno u domeni kvalitativne procjene pogodnosti tla sitnog mjerila.

Preporučujući primjenu dorađenog FAO okvira procjene zemljišta, predloženo je osnivanje „Projektnog savjeta za procjenu poljoprivrednog zemljišta Hrvatske" pri Ministarstvu poljoprivrede, Hrvatske agencije za poljoprivredu i hranu, Centru za tlo. S obzirom na dosadašnje probleme u radu bivšeg Zavoda, treba vjerovati da novom Zajedničkom poljoprivrednom politikom (ZPP) Europske unije za razdoblje 2021-2027. godine, dolaze bolji uvjeti i za nacionalnu poljoprivredu i funkcioniranje Centra za tlo.

Projektni savjet za procjenu poljoprivrednog zemljišta Hrvatske u interdisciplinarnom sastavu pedolog, agronom, ekolog, geograf, sociolog, ekonomist i IT specijalist, najprije bi morao organizirati izradu „Priručnika za procjenu poljoprivrednog zemljišta Hrvatske“, računajući na mogućnost izbora računalnog programa. Na primjer, primjena dorađenog Okvira za procjenu zemljišta FAO, ibidum obavljala se automatski s računalnim programom ALES (Rossiter i van Wambeke, 1995) ${ }^{4}$, koji omogućuje jednostavnu izgradnju ekspertnog sustava za procjenu zemljišta

Cilj programa ALES je da korisnici mogu instalirati i održavati ALES program na svom računalu, da ALES mogu koristiti kao alat u aktivnostima procjene zemljišta, da budu u mogućnosti integrirati ALES u svoj računalni sustav za procjenu zemljišta, koji može uključivati geografske informacijske sustave (GIS), baze podataka o prirodnim resursima, obrađivače teksta, proračunske tablice, softver za optimizaciju i podršku odlučivanju, kao i ALES.

Primjena programa $A L E S$ je predviđena za projektne ili regionalne procjene zemljišta nivoa rekonesansnih studija, fizibiliti studija ili za detaljna istraživanja i procjene na farmama-katastarskim česticama. ALES nije ekspertni sustav i sam po sebi ne uključuje nikakva znanja o zemljštu i korištenju zemljišta.

\footnotetext{
${ }^{4}$ Automated Land Evaluation System, ALES, verzion 4.5 Users's Manual, 1955
} 
Procjenitelji grade vlastite ekspertne sustave s ALES-om, usklađujući svoja znanja, zahtjeve i prilagodbe s lokalnim uvjetima i ciljevima procjene.

\section{ZAKLJUČAK}

U Hrvatskoj je u tijeku izrada strateških dokumenata s ciljem dugoročnijeg uređenja poljoprivrede u razdoblju nakon 2020. godine. Za očekivati je da će se u izradi strategije ispravljati dosadašnje greške kronično loših nacionalnih strategija poljoprivrede i ruralnog razvoja, uključujući uređenje zemljišno knjižnog sustava s preciznijim podacima o površini i bonitetu poljoprivrednog zemljišta. Hiperprodukcija zakona, pravilnika i uredbi do sada nije riješila probleme zemljišne politike. Ne smije se više odgađati usklađivanje katastra i gruntovnice sa stvarnim stanjem na terenu, jer je u najmanju ruku neodgovorno planirati sa podacima iz 3500 katastarskih općina, gdje njih 220 uopće nema knjige, a 70 posto njih je ažurirano u 19. stoljeću. Nema učinkovite strategije poljoprivrede i ruralnog razvoja, bez jasne i dugoročne zemljišne politike.

Izrada standardnog referentnog sustava „Procjena pogodnosti poljoprivrednog zemljišta Hrvatske“, primjenom digitaliziranog Okvira za procjenu zemljišta, FAO, ibidum, može zadovoljiti zahtjeve digitalizirane, održive i konkurentne poljoprivredne proizvodnje.

\section{LITERATURA}

1. Babić, Božica (2007.): Koliko Hrvatska ima obradive zemlje, www.poslovni.hr $>$ komentari > 08.01.2013.

2. Boban, T., (2012.): Značenje primjene komasacije u prošlosti i sadašnjosti uz vrednovanje nekoliko specifičnih lokacija u Požeško-slavonskoj županiji, Radovi Zavoda za znanstveni i umjetnički rad u Požegi, 1(2012), str. 273-291

3. Bogunović, M., Radica Ćorić, (2014.): Višenamjensko vrednovanje zemljišta i racionalno korištenje prostora, sveučilišni udžbenik, Mostar

4. Bogunović, M., Racz, Z., Vidaček, Ž., Kaučić, D., (1995.): Assessment of Soil Quality in Sauthern Dalmatia, Proceedings 19/2. International Conference, Bratislava, High Tatars, Slovak Republic

5. Bogunović, M., Vidaček, Ž., Racz, Z., Husnjak. S, (1997.).: Namjenska pedološka karta Hrvatske i njena uporaba, Agronomski glasnik 5-6, Zagreb

6. Chidley, T. R. E,. Elgy, J., Antoine, J.: (1993.): Computerized Systems of Land Resources Appraisal for Agricultural Development, Soil Resources, Management and Consrevation Service, FAO, Rome 
7. Dobos, E., Carré, F., Hengl, T., Reuter, H.I., Tóth, G., (2006.). Digital Soil Mapping as a support to production of functional maps. EUR 22123 EN, 68 pp. Office for Official Publications of the European Communities, Luxemburg.

8. Husnjak, S., (2014.): Sistematika tala Hrvatske, Hrvatska sveučilišna naklada, Zagreb

9. Kovačević, P., (1983.): Bonitiranje zemljišta, Agronomski glasnik, br. 5-6, Zagreb

10. Kovačević, P., i sur, (1987.): Nova metoda bonitiranja zemljišta u Hrvatskoj, Agronomski glasnik, 2-3, Zagreb

11. Kovačević, P., i sur, (1990.): Bonitet zemljišta i ekonomski uvjeti biljne proizvodnje kao zajednički pokazatelj proizvodne sposobnosti zemljišta, Agronomski glasnik, br.4, Zagreb

12. Kovačević, P., (1992): Bonitiranje zemljišta u funkciji čuvanja i podizanja plodnosti, Agronomski glasnik,vol.54, No 4, Zagreb

13. Kovačević, P.(1997.): Komentar karte pogodnosti tala istočne Hrvatske, Agronomski glasnik, vol 59, Zagreb

14. Rossiter, D. van Wambeke, A. (1995.): Automated Land Evaluation System ALES Version 4.65, ALES Project Department of Soil, Crop \& Atmospheric Sciences (SCAS) Bradfield Hall, 10th floor Cornell University Ithaca, NY 14853-1901 USA

15. Šimunić, A., Vidaček, Ž., (2001.): Specifičnosti litološkog supstrata i uporabne vrijednosti tala Hrvatskog zagorja, IX. kongres Hrvatskog tloznanstvenog društva s međunarodnim sudjelovanjem, Brijuni, 3-7. ISBN 953-6135-30 2, Agronomski fakultet, Zagreb

16. Škorić, A., Filipovski, G., Čirić, M. (1985.): Klasifikacija zemljišta Jugoslavije, Akademija nauka i umjetnosti, Sarajevo str 72

17. Vidaček, Ž., (1975.): Prilog korištenju nekih klasifikacija tala odnosno zemljišta pri namjenskim pedološkim istraživanjima na primjeru dijela srednjeg toka rijeke Plitvice, magistarski rad, Institut za pedologiju $i$ poljoprivredne melioracije, Zagreb

18. Vidaček, Ž., Šalinović, I. (1977.): Klasifikacija pogodnosti zemljišta za uporabu i mogućnosti njene primjene, Zemljište i biljka vol. 26, No 2, Beograd

19. Vidaček, Ž., Antonović, G.M.,. (1979.):"Osnovni principi procjene zemljišnog prostora". Unija naučnih društava Jugoslavije. Zemljište i biljka, vol. 28 (1/2), p. 51-85, Beograd

20. Vidaček, Ž., (1981.): Procjena proizvodnog prostora i prikladnosti tla za natapanje u Istočnoj Slavoniji i Baranji, disertacija. Poljoprivredna znanstvena smotra, br. 57, str. 471-502, Zagreb 
21. Vidaček, Ž., (1983.): Karakteristike i pogodnosti poljoprivrednog zemljišnog prostora za biljnu proizvodnju, Varaždinski zbornik radova povodom 800 godina grada, str. 111-118, Varaždin

22. Vidaček, Ž., Vančina, F., (1985.): "Karte upotrebne vrijednosti tala u funkciji prostornog planiranja i zaštite tla u Hrvatskoj". Acta Biologica Iugoslavica, Zemljište i biljka, Vol. 34 (3) p. 193-207, Beograd

23. Vidaček, Ž., i sur. (1998.): Evaluation of Soil Suitability for Regional Planning in Croatia. Agriculturae Conspectus Scientificus, Vol. 63, No. 3, 169-177, Zagreb

24. Vidaček, Ž., (2001.): Gospodarenje i zaštita tla u Hrvatskoj-Globalno stanje i preporuke, IX. kongres Hrvatskog tloznanstvenog društva s međunarodnim sudjelovanjem, Brijuni, 3-7. ISBN 953-6135-30 2, Agronomski fakultet, Zagreb

25. Vidaček, Ž.,Petrinec, Z., i sur. (2015.): Uzgoj vinove loze i proizvodnja vina u marijabistričkom kraju, Udruga vinogradara Marija Bistrica 15 godina, Marija Bistrica, ISBN 978-953-56452-0-7, CIP 000920345

x x x FAO (1976.): A Framework for Land evaluation. Soil Bull. No. 32. FAO, Rome and ILRI, Wageningen. Publ. No. 22

xxx Zakon o poljoprivrednom zemljištu, NN 20/18, 115/18, 98/19

xxx Zakon o zemljišnim knjigama, NN 63/19

xxx Pravilnik o načinu vođenja evidencije o promjeni namjene poljoprivrednog zemljišta, temeljem članka 23 stavka 4 Zakona 0 poljoprivredom zemljištu NN 20/18

xxx Pravilnik o evidenciji uporabe poljoprivrednog zemljišta, NN 54/19, https://narodne novine.nn.hr/clanci/sluzeno/2019 05-54-11035.html

xxx Pravilnik o mjerilima za utvrđivanje osobito vrijednog obradivog (P1) i vrijednog obradivog (P2) poljoprivrednog zemljišta, NN 23/19

xxx Statistički ljetopisi RH 2005-2017.

xxx Soil Conservation Service U.S., Department of Agriculture, Land Capability Classification, Agriculture Hsandbook No 210, 1961 
Adrese autora-Author's address:

Primljeno - Received:

Prof.dr.sc. Željko Vidaček dipl.ing agr., 30.10.2019.

e-mail: zvidacek@gmail.com

pedolog, umirovljeni redoviti profesor u trajnom zvanju, član Akademije poljoprivrednih znanosti, Zagreb-Marija Bistrica, 